\title{
Dilemma: The Art Teacher as a Liberal Educator
}

\author{
Pnina Bachar \\ Beit Berl College, Kfar Saba, Israel. \\ Email: Pninab@barak.net.il \\ Received March 18 ${ }^{\text {th }}$ 2011; revised April 15 ${ }^{\text {th }}, 2011$; accepted May $6^{\text {th }}, 2011$.
}

\begin{abstract}
This paper discusses the dilemma facing the art teacher as a liberal educator. The author first reviews the evolution of liberal education from ancient times, through the Renaissance to modern times and discusses, through an extensive bibliography, ancient and modern theories which have impacted on the concept of "liberalism," examining notions such as tolerance, individualism and autonomy which constitute the pillars of liberalism. The author discusses the contributions of philosophers and sociologists such as Thomas Hobbes, John Stuart Mill, Isaiah Berlin, and Will Kymlicka and then examines the two main approaches to liberalism: philosophical liberalism and political liberalism. The different emphases placed by these two approaches, on the individual and the group respectively, form the basis of the dilemma which faces the art teacher as a liberal educator. In order to understand the dilemma, the author draws a parallel between the two approaches and the role of the traditional art studio master and art educator. The goals of the studio master, who is devoted to the development of the individual, accord with philosophical liberalism, while those of the art educator, who is obliged to adhere to the demands of a school system, accord with political liberalism, which stresses equality for all. The ideal, says the author, resides in an amalgam of the two approaches and is symbolized in the term "artist-teacher" but she asks whether it is possible to truly merge the two approaches, at the same level, in the teaching process.
\end{abstract}

Keywords: Tolerance, Individualism, Autonomy, Freedom of the Individual, Liberal Education, Political

Liberalism, Philosophical Liberalism, Curriculum, Art Educator

\section{Discussion Background}

The art teacher is called an artist/teacher. This is a wellknown term among art professionals and its origins would seem to derive from the art studio where the student artists used to study. The term comprises two elements: the first is associated with the traditional master ${ }^{1}$ who taught a long course of studies in his studio (Bachar \& Glaubman, 2006) and who promoted excellence, the goal being to enable his students to be acknowledged as artists (Bachar, 2004) and to participate in the artistic discourse: the second element relates to the art teacher, who works among a community of teachers in a school and who is an educational figure, obliged to comply with the requirements of the educational system.

Both the master and the art teacher (or art educator) mediate between the student and art. Historically, both were influenced by social and economic factors, which impacted on the directions that took place in art education. I shall focus on understanding the term artist/teacher as an appellation for graduates of art teacher training, by analyzing their role in the context of literary theories on the subject and in the context of two well-known approaches of liberal education-political liberalism and philosophical liberalism. In conclusion I shall discuss whether it is possible to fuse these two approaches together in the role of the art teacher.

\section{A Brief Review of Liberal Education}

This review is important both for this paper and for the on-

${ }^{1}$ In this context, I shall call the artist who teaches in his private studio "master" in order to differentiate him, in this paper, from the standard meaning accorded to the term "artist". going discussion about art education. Liberal education is a concept which emerged in the nineteenth century, but its origins go back to the Renaissance and, to a certain degree, even to ancient Rome. Seneca, who was a Roman philosopher and teacher of Emperor Nero, defined the role of education primarily as the development of a person as a free spirit (Seneca, 1969). He believed that one could inculcate good qualities in man, such as courage, the ability to withstand temptation, loyalty, modesty and other qualities, which he deemed more important than standard disciplines. Art, in Seneca's time, was in the service of the Church and freedom in art, if it existed, was something that existed in secret. Only the cognoscente were able to identify the autonomous inner codes which artists planted in their works.

The Renaissance studio was humanist in terms of content and style. The humanists wanted to give everyone an education that would enable self-fulfillment. Renaissance intellectuals, who much admired the ancient world and borrowed many concepts from it, were responsible for transforming the concept of humanism into a fertile ground for the liberal approach that was to develop later. Thus, the origins of the concept "liberalism" can be traced, to a certain extent, to the fourteenth century and the emergence of the Italian Renaissance culture (Kristeller, 1992). Initially, liberal education constituted a classical education and, while no clear definition has been given of liberalism, (Bridgehouse \& Swift, 2003), researchers agree that liberal education is important for the stability of a state, and that democracy is the essence of liberal education (Levinson, 1999).

Liberalism, which derives from the humanist approach, views education primarily as the development of cognitive, moral and emotional qualities (Chrucky, 2003). A closer examination of the qualities, which liberal education seeks to 
develop, shows that the emphasis is placed on tolerance, individualism, autonomy and education towards a moral life (Gutmann, 1995). In view of the fact that the first three are considered important in art education, I shall focus on each issue separately:

Tolerance - the word has its root in the Latin term Tolerabilis, which means something that can be endured, a form of readiness to endure, perhaps passively, the ideas or actions of others. In his "Letter Concerning Toleration", Locke states: "For no man can, if he would, conform his faith to the dictates of another." (Locke, 1689). It is not enough to allow a community member $^{2}$ to express his opinion, it is also very important for the members of the community to listen and accept the other's opinion, even if it is contrary to the prevalent view. Tolerance of the other and the willingness to accept the other are the essential pillars of the liberal approach, and this should also be the case in the classroom where art students study. But the tolerance sanctified by liberalism also has limits, and this is part of the moral approach of liberalism. Actions which harm another person are unacceptable to society.

Individualism - when a society makes "tolerance" a central value, it means that it simultaneously seeks to accept the individual. Individualism is a major component of the personality of the liberal person, because it includes, by necessity, an awareness of his situation and actions. The individual person is aware of his individuality and acts as an individual and expresses his freedom in this way.

The beginning of spiritual individualism began with the Italian Renaissance. The historian, Burckhardt (1990), viewed Dante's "Divine Comedy" as a major work depicting spiritual individualism. In Burckhardt's view, the writing of a work such as the Divine Comedy testified to the liberation of man, made possible by the emergence of appropriate political and religious conditions in the fourteenth century. Until then, man was part of the whole.

The uniqueness of the individual and the important role accorded to the individual in liberal society exemplify, more than anything else, the difference between liberal education and preceding approaches. Mill emphasized individualism as an important basis for the development of the individual and as a social value. He acknowledged that not every person is able to develop individualism and that each person has his/her own way of fulfilling this important value. He distinguished two forms of individualism: individualism of strength and of development, "towards which every human being must ceaselessly direct his efforts and on which especially those who design to influence their fellow-men must ever keep their eyes," for which there are two requisites, "freedom, and a variety of situations," and from the union of these arise "individual vigor and manifold diversity" (Mill, 1989: p. 58).

While Kymlicka (Kymlicka, 1989) claims that individualism is the aspiration of modern liberal education, he argues with the definition of the essence of individualism in a multicultural society. Individualism, he notes, is viewed as an abstract entity while he places the emphasis on the social base that should be provided in order to enable individuals to make the best choices

\footnotetext{
${ }^{2}$ It is important to stress the role of the community in a liberal society that is made up of individual, autonomous members who build the community together. Livnat (2000) "the individual and the community, communitarian criticism of the High Court of Appeal” 205/94 Nof v. Ministry of Defense. Mishpatim 31219.
}

for themselves. In art education, the individual is one of the most important values, particularly when the aim of the education is to train the artist, the person who will take part in the artistic discourse, the person who will dare to express him/ herself in an original way and breach known patterns.

One also finds, among liberals who believe that individualism is vital for society, criticism of the fact that individualism encourages alienation from social ties and self-centeredness (Sher, 1997).

Autonomy or freedom of the individual - a combination of terms which has received endless definitions. Kant claimed that people only possess true freedom if their understanding is autonomous and they are able to implement their decisions (Wood, 2005). Liberal society is connected to the value of autonomy. The ideal of autonomy is the ability to control the course of one's life and, to a certain extent, one's fate. A society, which is committed to the value of autonomy, is obliged to assist its members to obtain the conditions which will enable them to pursue autonomous lives. Autonomy is thus distinguished from freedom, since autonomy is the means which will enable a person to acquire positive freedom (Guntovnik, 2003).

In this context, Hobbes defined autonomy thus: "By liberty is understood, according to the proper signification of the word, the absence of external impediments; which impediments may oft take away part of a man's power to do what he would, but cannot hinder him from using the power left him according as his judgment and reason shall dictate to him” (Hobbes, 1997).

Hobbes held that freedom is achieved when external obstacles do not prevent a person from fulfilling his/her goal. Liberal educators will thus try to accord to their students freedom from external obstacles, in order to enable them to develop their talents. Berlin (Berlin, 1969), expressed reservations regarding freedom from external obstacles, noting that certain obstacles are inevitable since man, by nature, depends on others. He wrote that the insights we gain about ourselves depend on the social environment in which we live. Freedom from external obstacles is not the only freedom required by art students, particularly if their goal is to become an artist. The art student requires positive freedom which derives from within his/her own personality.

Liberal thinkers (Yona, 2007; Gutmann, 1995), who have commented on education, note that liberal philosophy follows two main approaches: political liberalism and philosophical liberalism (Gutmann, 1995). The first is important, they say, for the stability of the state for it encourages the development of autonomous citizens who possess a strong sense of justice, but followers of this approach do not necessarily have to apply liberal principles in their lives or homes. The second aims to educate citizens to apply freedom of choice in their personal lives and display autonomy in their choices (Gutmann, 1995). Each approach has a different way of viewing society. The first looks at society in general and considers the individual as part of the whole, while the second focuses primarily on the individual.

\section{Political Liberalism and Philosophical Liberalism}

Political liberalism attributes prime importance to mutual respect and tolerance of others (Levinson, 1999), and emphasizes 
other rights such as freedom of expression, freedom of religion, freedom to own private possessions, physical freedom, and the freedom to do whatever does not harm others. It is, however, possible that the product of such an education will distinguish between rights that should be accorded to those who belong to his/her social, ethnic group, skin color, etc., and rights which should be accorded to others. According to this approach, the "individual” is part of the group (Kymlicka, 1989) and derives his/her strength and definition from the group, while the latter defines his/her external limitations. Culture is the culture of the group and the individual identifies with the culture of his/her group. Kymlicka bases himself on Taylor (Taylor \& Pippin, 1979) who supports the views held by Hegel, in his definition of freedom and the importance he attributes to the community as a major factor in the choices made by the individual. Kymlicka (1989) examines freedom of the individual from a critical perspective. What is important, from his point of view, is the ability to view different life options and to choose from them (Margalit \& Halbertal, 1998).

Philosophical liberalism: this approach attributes prime importance to the individual and to autonomy (Gutmann, 1995). Here, the major factor is the "individual" and the manner in which the individual makes his/her own decisions. In this approach, the individual is placed at the center and the emphasis is on his/her right to an individual life, autonomy and culture (Margalit \& Halbertal, 1998).

These two approaches to the individual are important to our attempt to understand liberal education and its application to the artist/art teacher.

\section{The Studio Master as a Philosophical, Liberal Educator}

As mentioned above, the artist has an affinity with the studio master. The latter constituted a private framework free from external limitations, where the personal views of the artist reigned supreme, shaping the work and instruction that took place in the studio. The master chose his students from the many talented, motivated youth who sought his teaching. During their training, the students pursued their visual "talk" together with the usual means of communication used by others (Noy, 1999). In his book “On Freedom," Mill comments on the uniqueness of talented individuals and their importance to society: "Persons of genius, it is true, are, and are always likely to be a small minority; but in order to have them, it is necessary to preserve the soil in which they grow. Genius can only breathe freely in an atmosphere of freedom. Persons of genius are, ex vi termini, more individual than any other people” (Mill, 1989: p. $65)$.

The assumption of this form of instruction was that students possess the ability to learn and, through knowledge, are able to fulfill their freedom. This is an intermediary stage acknowledged by the teacher and the student. Locke (1690) refers to this when he talks about the authority of the father: "children are not born in a full state of equality, though they are born to it." A student's inborn talent was acknowledged by his/her environment and teacher, and it was then up to the student to develop in a supportive, stimulating society and practice his/her skills again and again. Vasari quotes Lodovico, father of Michelangelo:
"1488. I record the first day of April, that I, Lodovico di Leonardo di Buonarrota, placed Michelangelo, my son, with Domenico and David di Tommaso di Currado for the three years to come, on these terms and conditions, that the said Michelangelo shall remain with the above-named persons for the said period of time, in order to learn to paint and to exercise that vocation; that the said persons shall have command over him; and that the same Domenico and David shall be bound to give him in those three years twenty-two florins of full weight, the first year six florins, the second year eight florins, and the third ten florins; in all, the sum of ninety-six lire.” (Vasari, 1996: p. 644).

The studio master strove to train his students to be artists and the ideal and apex of the training was to achieve the rank of master:

"Now it happened that when Domenico was at work on the great chapel of S. Maria Novella, one day that he was out, Michelangelo set himself to draw the staging from the reality, with some desks and all the appliances of art, and some of the young men who were working there. Whereupon, when Domenico had returned and seen Michelangelo's drawing, he said: 'This boy knows more about it than I do,' and he was struck with amazement at the novel manner and the novel method of imitation that a mere boy of such tender age displayed by reason of the judgment bestowed upon him by Heaven, for these, in truth, were as marvelous as could have been looked for in the workmanship....” (Vasari, 1996, p. 645).

The deciding moment came when the student broke the mould. It was not a simple process, since the training consisted of practice aimed at achieving a desired, ideal result. In the course of his/her studies, the student did not absorb, at least consciously, educational influences which encouraged breaking the desired mould. So how did this process occur? And why, when it did take place, was it considered the apex of the process? What happened in that studio which enabled the student to realize his/her freedom and choose an original way of expressing ideas? We can learn about this from Mill (1989), when he expresses his opinion on the development of an individual person (see page 137 above).

Although Mill does not relate specifically to the artist, we can apply what he says to the training of the student in the art studio. The entire process of teaching in the studio was a collaboration between the master and the student or apprentice, later, the trainee or disciple. The relationship between the master and his apprentices was a hierarchical one. The master had an honored status. He was an artist who had demonstrated his talents and achieved renown because of his skills and his art and, as such, was a figure to emulate. A master was an artist who had fulfilled his talents and achieved his goals. When an apprentice showed potential, the master enabled the student to experience, in the words of Mill, a wide spectrum of situations and to develop his skills. The relationship was a personal one, each student being acknowledged in his/her own right, as a person of talent.

Both teacher and student were aware that this period of training was temporary, and would end once the student matured. Equal rights, according to this approach, consisted in the opportunity given to an individual to fulfill his/her talents and develop his/her skills as much as possible, free from external interference or limitation. What is the meaning of this auton- 
omy? To what end did the artist train the student? Who, in his eyes, represented the ideal graduate? Mill stressed the privilege of individuals to interpret their experiences in their own unique way.

"Nobody denies that people should be so taught and trained in youth, as to know and benefit by the ascertained results of human experience. But it is the privilege and proper condition of a human being, arrived at the maturity of his faculties, to use and interpret experience in his own way.” (Vasari, 1996, p. 59)

The goal was thus defined from the start-in their training, the students would develop their personal talents and artistic skills in order, when the time came, to formulate their own, unique interpretations. This form of training obligates the master to accompany the student at every stage. It is a close relationship with an element of obligation; it is an education which is not limited to professional training but enlarges the arena and considers the student holistically. A similar educational process is seen in Emile, where Rousseau educates Emile and oversees every detail of his life: his training, dress, bed, etc. Education does not rest with training. It is a total process and the dialogue between the teacher and the student is not limited to studying and to the period of study. It is a broad and comprehensive process.

\section{The Parallel between the Studio Master and the Philosophical, Liberal Educator}

The goals of the master are congruent with the goals of the philosophical, liberal educator. The latter tries to develop freedom and autonomy and enable students to make their own choices from inner, personal considerations. Education is comprehensive and does not focus solely on the student's professional training. The educator pays as much attention to the student's personality as to his/her abilities. Noy (1999) notes that artistic activity is a process, which merges two worlds: the inner world and the world of reality. He describes this activity as a way of integrating and understanding reality in the language of emotions, and integrating and understanding emotions and experience in the language of reality.

The goal of the master is to develop his students' individuality. A uniform product is considered a failure. Only students who succeed in breaking through the artistic discourse to formulate their own original ideas are viewed as having successfully graduated from the studio.

\section{The Art Teacher as a Political, Liberal Educator}

In contrast to the master, the art teacher positions himself in a school, at the same level as other disciplines. Historically, art teachers, as educators, viewed art as a means of developing the intellect, and therefore did not focus specifically on the use of techniques. This approach always existed side by side with the traditional studio approach. Already in the fifth century, Plato (Plato, 1983) sought to educate the guards of Polis through art. He felt the power of art as a means of transmitting hidden messages in a mysterious way, as a medium that impacts on man (Roznov, 1968). The approach, based on the belief that the senses, which a child develops though the arts, will influence the future shaping of his/her personality as an adult, emerged primarily in the $18^{\text {th }}$ century when art began to be taught in schools. Talent was considered not obligatory in order to study art, and anyone could study art, if they practiced basic techniques. Swiss pedagogue, J. H. Pestalozzi (1746-1827) put this approach into practice when he transposed drawing into a linear A-B consisting of straight and circular lines. According to Pestalozzi, learning to paint should not involve thought or emotional expression. Pestalozzi emphasized skills of the eyes and the hands and the importance of practicing these skills in order to train students in other professions and develop general observation skills in daily life.

The talents, emphasized by the political, liberal approach, are primarily cognitive skills: knowledge, development of insights and clear thinking. The practice of art does not aim to enable freedom of expression, but to stimulate rational thought. Graduates of this approach have the ability to make choices: they possess the ability to analyze reality, think in the abstract and generalize. As "individuals," they are part of society and it is considered important for them to develop cognitive abilities and a sense of aesthetics, and to be a part of their culture and tolerant towards "others." The choices made by the individual are personal, but the limits and limitations imposed derive from the fact of being an individual within a society and culture.

\section{The Parallel between the Art Teacher and the Liberal, Political Educator}

The role of the art teacher is primarily a social one: since students are viewed as part of a community and culture, the art teacher tries to develop their talents and knowledge, in order to enable them to function as "individuals" within the community. The teaching focuses on the subject of art and does not relate to the students in general terms, as in an art studio. The art teacher is defined in terms of time and place, is circumscribed by other school disciplines, imparts an equal education to all (not just to talented students), and emphasizes cultural knowledge, respect and tolerance for the other as an important element of art education.

\section{In What Way Do the Two Approaches Merge in the Figure of the Art Educator?}

Art teachers are faced with an almost-impossible task: on the one hand their goal is to develop the skills of their students and enable them to express themselves via the complex tools imparted by art; on the other hand they have to adhere to societal needs imposed by the educational system in which they work. Art teachers and programs are required to cater to issues such as, professional training, creative development, learning difficulties of students, while at the same time developing the skills of talented students. Societal pressure also requires art programs to enable students to fully experience their environment and to be critical of the visual messages around them. Concomitantly, the goals of art students differ from those of the studio apprentice: art students today are highly aware of social requirements and demand that the educational system train them accordingly.

An in-depth observation of art classes which try to combine the two approaches immediately exposes the dilemma faced by 
art teachers. How should they present art material to their students? What points should they emphasize? Which approach is the most important and how can the two approaches be combined? For instance: should art teachers focus on practical experience with color and materials and encourage their students to develop insights and intimate feelings to the point that art will seep into their most inner being. Or should they develop experience only up to the level of cognitive understanding of the artistic idea and emphasize the social role of the artist? How can art teachers combine the historical roots and traditional status of the studio master with their role as teachers working within an integrated educational system?

The artist/teacher represents a role whose roots are steeped in the two, different liberal approaches. The first (like the studio master) is that of the philosophical, liberal educator who focuses on developing the student as an individual who will tread new ground and who, as a complete educator, views the student as a whole being. The second, that of the art teacher, emphasizes education towards tolerance and acceptance of the other. The art teacher focuses on knowledge, theoretical, critical skills and the ability for verbal expression in relation to a work of art. As part of the educational system, the art teacher is obligated equally to all his/her students. The one focuses on the senses and, through them, on thought, while the other focuses first on thought and rational analysis.

Democracy, for its part, requires an equilibrium between the two approaches (Zimmerman, 1997) — between the development of excellence among talented students and the requirement of educational programs for equality towards all students. As a society, we are obligated to safeguard this equilibrium, since preference towards either side encourages or aristocracy or totalitarianism. The art teacher trains and encourages talented art students but, at the same time, is obligated to enrich all his/her students in theoretical and practical knowledge of art. Gardner (Gardner, 1961) proposes an approach which encourages excellence in talented students, while at the same time encouraging excellence in all students. This means enlarging the circle and applying the techniques of the studio to a regular school. When the goals of a teacher are steeped in the philosophical, liberal approach, the teacher enables a style of teaching that is intimate and suited to all students, according to their needs. The skills which the art teacher imparts are: a sensitive eye, the ability to express oneself in an original way, the desire to contribute something new, and the emotional ability to break through existing patterns. These are skills which the students will be able to apply to every domain, not just to art.

Conclusion: the true artist/teacher integrates in his/her work both political liberalism and philosophical liberalism, viewing students as individuals and adapting teaching programs to their personality and needs. The art teacher, on the other hand, has to take into consideration the educational system he/she works in and its requirements. The merging of these two approaches in the figure of the art teacher is complex and one can ask whether it is truly possible for art teachers to use these approaches at the same level, in the teaching process. It could well be that this is too great a task to ask of the art teacher. However, in this modern age, when art is primarily taught in a school framework, we would like to believe that the art educator is capable of implementing both approaches; developing the unique, individuality of his/her students while, at the same time, promoting equality and enabling students to become integral parts of the society they live in. The two approaches, inherent in the term artist/teacher, point to the essential dilemma faced by the art teacher. The possibility of merging these two approaches in a school environment and the different ways in which art teachers combine them in class are issues which will be discussed in subsequent research.

\section{References}

Arbel, B. (2000). The Italian Renaissance: Development of secular culture. Humanist Education, 1, 76-77.

Bachar, P. (2002). Methods for developing autonomous learning in the plastic arts. Ph.D. Thesis, Ramat Gen: Bar-Ilan University.

Bachar, P. (2004). The art teacher as perceived by educators and artists. In G. Melzer (Ed.), Hinuch ve Hanicha (pp. 199-213). Kfar Sava: The Art School of Bet Berl Academic College.

Bachar, P., \& Glaubman, R. (2007). The image of the student and the teacher in the plastic arts curricula for elementary and junior high schools in the period 1906-1993. Dapim, 44, 148-179.

Bachar, P., \& Glaubman, R. (2006). Policy and practice of art teaching in schools as perceived by educators and artists. Art Education Policy Review, 108, 3-13. doi:10.3200/AEPR.108.1.3-13

Bridgehouse, H., \& Swift, A. (2003). Defending liberalism in education theory. Journal of Education Policy, 18, 355-373. doi:10.1080/0268093032000106820

Berlin, I. (1969). Four essays on liberty. Oxford: Oxford University Press.

Burckhardt, J. (1990). Civilization of the Renaissance in Italy. London: Penguin Classics.

Chrucky, A. (2003). The aim of liberal education. Digital Text International.

Efland, A. (1990). A history of art education, intellectual and social currents. In Teaching the visual arts. New York, NY: Teachers' College, Columbia University.

Gardner, J. (1961). Can we be excellent and equal too? New York, NY: Harper and Row.

Gibbs, B. (1979). Autonomy and authority in education. Journal of Philosophy of Education, 13, 119-132. doi:10.1111/j.1467-9752.1979.tb00527.x

Gutmann, A. (1995). Civic education and social diversity. Ethics, 105, 557-579. doi:10.1086/293727

Guntovnik, G. (2003). The right to culture in a liberal society and in the State of Israel. Iyunei Mishpat, 27, 23.

Hobbes, T. (1997). Leviathan. Cambridge: Cambridge University Press. Kymlicka, W. (1989). Liberalism community and culture. Oxford: Clarendon Press.

Kavolis, V. (1974). Arts, social and economic aspects. Encyclopedia Britannica. 102-122.

Kris, E. (1952). Psychoanalytic explorations in arts. New York, NY: International University Press.

Kristeller, P. O. (1992). Renaissance humanism and its significance. In M. A. Di Cesare (Ed.), Reconsidering the Renaissance (pp. 29-43). Binghamton, NY: Center for Medieval and Early Renaissance Studies.

Levinson, M. (1999). Liberalism, pluralism, and political education: Paradox or paradigm? Oxford Review of Education, 25, 39-58. doi:10.1080/030549899104116

Locke, J. (1689). A letter concerning toleration. Indianapolis: Hackett Publishing.

London, P. (1989). No more secondhand art awakening the artist within. Boston: Shambhala.

Mill, J. S. (1989). On liberty and other writings. Cambridge: Cambridge University Press.

Margalit, A., \& Halbertal, M. (1998). Liberalism and the right to culture. In M. Meutner, A. Sagi and R. Shamir (Eds.), Multiculturalism in a Jewish democratic state (pp. 93-105). Tel Aviv: Ramot Publish- 
ing.

Maslow, A. (1964). Religion, values and peak experiences. Columbus: Ohio State University Press.

Noy, P. (1999). Psychoanalysis of creative art. Tel Aviv: Modan.

Orwell, G. (1949). Nineteen eighty-four. London: Secker and Warburg. Plato (1983). The republic, book II. Indianapolis: Hacket Publishing.

Ravitzky, A. (1995). Issues of tolerance in a Jewish framework: Between pluralism and paternalism. In A. Kasher and A. Nimdar (Eds.), Midot ve Regashot. Ramat Gan: Hoshen LeMishpat Publications.

Rice, E. F., \& Grafton, A. (1994). The foundations of early modern europe 1460-1559. New York: Norton \& Co.

Rogers, C. (1969). Freedom to learn: A view of what education could become. Columbus, Ohio: Charles Merill.

Rousseau, J. J. (1762). Emile: Or on education. London: J. M. Dent.

Roznov, A. (1986). The ideological and utopian foundations of education. Tel Aviv: Ramot Publishing.

Seneca, L. A. (1969). Letters from a stoic. Translated by R. Campbell, London: Penguin.

Sher, G. (1997). Beyond neutrality: Perfectionism and politics 12.
Cambridge: Cambridge University Press. doi:10.1017/CBO9780511609169

Strauss, L., \& Hutchins, R. M. (1959). What is liberal education? The 10th Annual Graduation Exercises of the Basic Program of Liberal Education for Adults.

Taylor, C., \& Pippin, B. R. (1979). Hegel and modern society. Cambridge: Cambridge University Press.

Vasari, G. (1996). Lives of painters, sculptors and architects, 2, London: Everyman's Library.

Wood, A. W. (2005). Kant. Oxford: Blackwell.

Yona, Y. (2007) The "just" and the "good": Political liberalism as viewed by education. In D. Atas and D. Heyd (Eds.), The just teacher: A critical review of the theory of John Rewls. Jerusalem: Magnet Publishers.

Zimmerman, E. (1997). Excellence and equity issues in art education: Can we be excellent and equal too? Art Education Policy Review, 98, 4. doi:10.1080/10632913.1997.9936391 